\title{
Educação para a comunidade: algumas perspectivas para 0 ensino de história
}

\author{
EDUCATION TO COMMUNITY: ANY PERSPECTIVES TO THE TEACHING OF \\ HISTORY ABSTRACT
}

Philippe Delfino Sartin ${ }^{1}$

\begin{abstract}
RESUMO: A proposta deste artigo é, numa palavra, traçar um itinerário, uma espécie de programa teórico, como perspectiva para o Ensino de História, resumindo nossa posição com relação ao sentido a ser ensejado por qualquer meio de Educação - especialmente a Educação Formal, por ser o mais abrangente - como um valor transcendente à prática da Ciência da História, que dela se serve, constituindo-a em sua própria legitimidade. Nossas observações terão como ponto de partida a Teoria da História de Jörn Rüsen e a "Filosofia do Diálogo" de Martin Buber.
\end{abstract}

Palavras-chave: Comunidade. Formação. Ensino de História.

\begin{abstract}
This article intents to draw an itinerary, such a theoric program, as one perspective to the Teaching of History, summarizing our position to the aimed sense for any kind of education - especially the Formal Education, because it's the widespreadest - as a transcendent value to the practic of the Science of History, that uses it, constituting it in its legitimacy. Our observations shall take, as an initial point, the Jörn Rüsen's Theory of History and the Martin Buber's Dialogical Filosofy.
\end{abstract}

Keywords: Comunit. Formation. Teaching of History.

\footnotetext{
${ }^{1}$ Mestrado em História pela Universidade Federal de Goiás.
} 
"A história é mesmo importante para a vida das pessoas, mas elas têm que saber contar uma História não só de guerra, morte e essas coisas, mas sim fazer uma história de amor, em que conta [...] coisas legais para o povo parar de brigar e guerrear uns com os outros. É isso que eu acho." 2

\section{Introdução}

Encontra-se entre as muitas urgências do nosso tempo a clareza das posições ideológicas. Dizer de uma vez por todas, de maneira aberta e sincera, o que é que se pensa sobre um assunto ou outro.

Antes: o que de fato - dado o espetáculo do embrutecimento dos meios de informação onde pululam 0 interesse evanescente e 0 sensacionalismo medíocre -, o que de fato, repito, se nos impõe como um assunto.

Ao abordar a complexa temática do Ensino de História - e este é, sem dúvida, um assunto a ser debatido, um imperativo que a muito se deslinda, ou que pode deslindar imperativos mais abrangentes - nos deparamos com uma série de posições mal afirmadas, práticas mal concebidas e, aliado a um mesquinho desinteresse pelo tema por parte dos historiadores profissionais, a dificuldade em tornar significativo o estudo da História entre as crianças e adolescentes.

Esta dificuldade não é um falso problema, um argumento sofístico (literariamente repetido ad nauseam), ou um arcabouço retórico; porque podemos efetivamente afirmar: não desejamos tornar nossos alunos historiadores, garantir a reposição dos contingentes para os cursos de História. Mas daí não se segue, de maneira alguma, que se tenha justificado a existência efetiva, garantida pelos currículos e pelas provas do Vestibular, da disciplina de História como componente do Sistema Básico de Educação.

Pois se existe alguma coisa que não pode ser aceita como dogma, que não se reserva este direito - hesitamos em dizer "privilégio" - é a disciplina da História, uma vez que um de seus objetivos mais explícitos é

\footnotetext{
${ }^{2}$ Aluno do $9^{\circ}$ ano do Ensino Fundamental, em resposta a questionamento sobre o "sentido da História".
} 
dar conta da processualidade da constituição das verdades, colocá-las em seu lugar, por assim dizer, como sugere Michel de Certeau (2010, p. 65).

Disciplina: a sua ascese é a argumentação.

Enganar-nos-íamos, entretanto, se alijássemos da sala de aula esta performance argumentativa, reservando-Ihe as cátedras universitárias como palco exclusivo. Pelo contrário, a missão mais elevada do professor de História será capacitar os seus alunos a adentrar na arena e tomar sua posição no debate - a sala de aula, não mais o espetáculo do cristão e do leão, torna-se um local privilegiado para a constituição de habilidades específicas de argumentação, reflexão e capacidade de referência.

Dito de outra maneira: o historiador profissional, quando atua como professor de História, tem, como principal objetivo, realizar uma mediação, entendida não como a interpretação e exposição de um conteúdo previamente determinado a indivíduos que são a mais pura receptividade (pois não o são), mas antes, no sentido de ajudar seus alunos a desenvolver um pensamento histórico baseado em critérios otimizados de racionalidade.

Tal posicionamento se justifica se admitirmos a tese de Jörn Rüsen de que "em sua vida em sociedade, os sujeitos têm de orientar historicamente e têm de formar sua identidade para viver - melhor: para poder agir intencionalmente" (2007, p. 87). Esta ação intencional exige uma autoreflexão, que, como sabemos há muito tempo, nem sempre é verificada, embora acreditemos que sempre seja possível. Somos otimistas. De que vale a desesperança diante de uma realidade muitas vezes desesperadora? Sim: é o velho projeto iluminista, a proposta de emancipação, de capacidade de autodeterminação como mecanismo de interação social. Valores como cidadania e democracia são, afinal de contas, assumidos como elementos de uma formação humanista.

Tais valores podem ser defendidos através do Ensino da História, como quaisquer outros o podem. Mas não é esta a função de ensinar História. A vontade de verdade, deve prevalecer sobre a vontade de poder, como diz Rüsen. Pois o discurso político pode se servir de outras racionalidades, que não a História, para se legitimar. Este objetivo, 
presente numa proposta de ensino que privilegie apenas a capacitação para engrenar um sistema que, de resto, só procura engrenagens, seres sem face, como o agente secreto de Johnny Rivers, pode ser simplificado com a expressão "educação para o mercado". Este é um grande problema do ensino técnico, se este sacrifica o aspecto emancipador da educação em prol de compromissos de um desenvolvimento desorientado e insustentável, buscando, não raro, excluir dos currículos disciplinas como História, Sociologia e Filosofia.

Pelo contrário, capacitar o aluno a questionar o mundo que o cerca, a expor seus pontos de vista de maneira racional, a conviver com as diferenças e a situar-se entre os demais, através da constituição de sua identidade, são, para nós, o objetivo urgente da educação. ${ }^{3}$

Ora, o que tentaremos defender (com base em teoria e em experiência na sala de aula) é que a História, enquanto disciplina escolar pode proporcionar aos jovens tal capacitação.

Nossa pergunta é a seguinte: como o aluno que representa o passado através de uma racionalidade metódica conscientemente orientada pode chegar a relacionar-se como seu mundo - a um só tempo, familiar e estranho, preservando-lhe ambos os sentidos - isto é: como partir da representação e chegar à relação? Como, da História, pode surgir a Comunidade?

\section{História Como Prática Racional}

Trabalhando com uma turma de $9^{\circ}$ ano do Ensino Fundamental - o que, no Brasil, corresponde a uma faixa etária que vai dos 13 aos 15 anos buscamos realizar um teste, uma experiência, não certamente hermeticamente controlada, mas, enfim, uma experiência. Admitimos como pressupostos que os alunos possuem um pensamento histórico (pelo fato, algo banal, de serem humanos) e um senso de comunidade - de identidade e reciprocidade em seus grupos sociais.

\footnotetext{
${ }^{3}$ Para nós e para muitos, muito mais importantes, de um ponto de vista acadêmico e cultural.
} 
Admitimos também, como hipótese de trabalho, que os mecanismos de verificação, reflexão e intersubjetividade presentes na racionalidade da História como Ciência (MARTINS, 2002, pp. 11-25), seriam, não apenas aplicáveis no ambiente da sala de aula, mas virtualmente potencializadores dos predicados teoricamente reputáveis aos alunos - isto é, que estudando história como os historiadores a estudam, os estudantes potencializariam seu pensamento histórico de um ponto de vista racional (RÜSEN, 2007, p. 94), bem como seriam mais capazes de idealizar seus próprios valores no âmbito da comunialidade (BUBER, 2008, p. 89) da vida prática.

Se nos acusarem de instrumentalizar a disciplina da História em prol de valores como a democracia e o humanismo, podemos simplesmente dizer que é melhor que instrumentalizá-la em prol de projetos de dominação e opressão. E de resto, são estes valores que tornam possíveis a racionalidade da História como disciplina - se não houvesse espaço para o debate e para a argumentação, ou ainda, uma insatisfação, em vários níveis da sociedade, com a quantificação do que é especificamente humano, não seria possível, nem mesmo desejável, algo como "História".

O conteúdo a ser trabalhado junto aos alunos era "Ditadura Militar no Brasil" ${ }^{4}$. Certas palavras-chave vêm à mente quando tocamos no assunto, como tortura, exílio, terror. Pré-conceitos que pedimos que os alunos expusessem, sem quaisquer consultas ao livro didático, numa folha de papel, avulsa. De fato, encontramos estas noções nas diversas respostas que os alunos escreveram: "governos torturam as pessoas que eram contra a ditadura", "censura contra os cantores", "pessoas eram fuziladas", "quem fosse contra o governo era torturado e preso e até condenado à morte".

"Agora, a tarefa de vocês será escrever uma História da Ditadura Militar. Vamos ter cinco aulas sobre o tema, e, ao fim, vamos comparar essas primeiras impressões com as futuras opiniões de vocês".

"Vocês não irão consultar o livro didático, nem a internet, a princípio. Ao invés disso, se basearão em documentos, em fragmentos daquela época, como fazem os historiadores. Vocês irão rastrear aquela época, como faz um detetive. Cada documento é uma pegada".

\footnotetext{
${ }^{4}$ Dentro da nossa perspectiva, o mais importante deixa de ser o "tema" da aula, ou o seu "conteúdo", e passa a ser o procedimento cognitivo empregado: escrever uma narrativa.
} 
"Mas há algumas palavras que funcionam como se fossem chaves para aquela época. Nós as chamamos de conceitos. São palavras que nos dão acesso àquela época. Vocês vão ter de usá-las, mas, antes, terão de descobri-las, e refletir sobre elas, em sala de aula".

"Além disso, vocês irão debater os documentos entre vocês. Isso permitirá que vocês tenham opiniões diferentes sobre o assunto, e mais segurança quando escreverem esta História".

Após estas preliminares, foram distribuídos entre os alunos um total de 18 fragmentos, como uma espécie de corpus documental, contendo letras de canções, imagens da época (charges, fotografias), depoimentos e relatos.

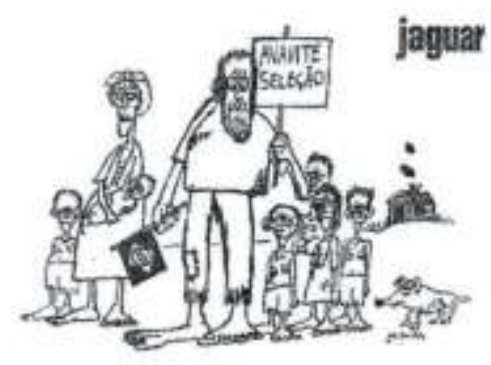

Figura 1 - Exemplo de ilustração colocada à disposição dos alunos para análise

Evidentemente, esta simulação do trato das fontes permanece imperfeita, pois a documentação não se encontra reunida num corpus. Aliás, "o que", efetivamente é documentação, ou, o que o fato de haver um corpus documenta, é outra questão. Mas, por questões de ordem objetiva (como a pressão exercida pela escola no sentido de "cumprir o currículo" e avançar em outros conteúdos), não foi possível vasculhar, com os alunos, a internet ou algum arquivo sobre a ditadura ${ }^{5}$, o que seria ideal.

Além disso, dispusemo-Ihes um relato de tortura ocorrido em 1969, em MG, quando uma série de guerrilheiros foi capturada. Este relato se encontrava no livro A ditadura envergonhada de Élio Gaspari (2002).

As canções foram todas executadas em sala de aula. A musicalidade é com certeza, assim como a visualidade, um meio de acesso e de empatia

${ }^{5}$ A Faculdade de História da UFG possui um laboratório e um projeto de divulgação sobre a Ditadura Militar, que, pelas questões que expomos, não foi possível consultar. 
com uma dada realidade. Neste sentido, saber o que era, e o que não era audível, é da maior importância para a compreensão do tema.

Os alunos assistiram às aulas e interagiram com a documentação. Após cinco encontros, foram recolhidos os trabalhos. Apresentemos os resultados a partir de trechos escolhidos de cada uma das "Histórias da Ditadura" que nos foram apresentadas, juntamente com a capacidade reflexiva desenvolvida. ${ }^{6}$

a) contextualização - capacidade de relacionar os acontecimentos no Brasil a um contexto internacional

"O Brasil foi prejudicado demais com esse golpe militar que começou por causa de uma divisão do mundo. Eles (sic) não deixavam a população escolher o que queria ser. Quem iria apoiar as personalidades deles era definido pelos militares, autoridades ou quem simplesmente quem tinha $o$ poder. A liberdade de hoje foi conquistada com muita luta no passado e em 1985 foi o fim de todo o sofrimento".

Percebemos claramente a relação estabelecida entre passado e presente, a ligação entre um presente democrático e a luta pela democracia, no passado. É uma imputação causal que considero positiva, pois se esquiva de um raciocínio que atribua a volta das liberdades democráticas (como o voto) à ação dos governantes, por exemplo, Figueiredo. Abre espaço para o individual dentro da História, embora valore negativamente o período militar $^{7}$. Por outro lado, consegue relacionar o contexto brasileiro à Guerra Fria. Este link com o passado pode ser aproximado de uma constituição genética de sentido, conforme teoriza Jörn Rüsen: "de mudanças que levem das formas de vida estranhas ou alheias às próprias" (2007, p. 62).

b) conceituação: reflexão sobre as assertivas acerca de uma dada realidade

\footnotetext{
${ }^{6}$ Cada trecho pertence a um aluno diferente, cujo nome não será mencionado. Diremos simplesmente "aluno $A$ " ou "aluno B".

7 Este tipo de postura, ainda enraizada no senso comum, se encontra atualmente criticável, conforme nos diz Carlos Fico, (2004, pp. 29-60), agora que "tabus e ícones da esquerda vão sendo contestados".
} 
"A ditadura não foi uma época sangrenta ou covarde para a maioria dos brasileiros, mas a oposição sofria com perseguições, ameaças e também com o exílio".

Aqui temos a habilidade de crítica e distinção com relação a visões estereotipadas. Em relação às primeiras observações, pedidas no início da atividade, a mesma aluna havia escrito: "Opressão, medo, guerras e revoltas (...) só as famílias ricas são beneficiadas". Significa uma mudança no pensamento histórico, que ganha racionalidade pela referencia a fontes e a outros pontos de vista.

Ainda, da mesma aluna:

"Para ficar mais bem explicado: o exército oferece uma oportunidade de livrar o país do governo comunista e dá um golpe não só no presidente como também dá no país, mesmo relutando em dizer. A princípio não foi um golpe com segundas intenções, mas depois de ser efetuado, já é outra história."

Aqui percebemos a seleção de acontecimentos e o estabelecimento de um sentido que os una na forma de uma narrativa. A expressão "golpe no país" representa a retrospecção em direção a uma compreensão pela via da narração - a aluna teve de recuar para atribuir outro sentido ao acontecimento, ao invés de simplesmente relatá-lo. Isso demonstra uma preocupação com a significação da ação do governo na sociedade, principalmente se considerarmos que, logo abaixo, a aluna diz que as composições de artistas como Chico Buarque e Geraldo Vandré eram um direito de resposta. A percepção das relações de força presentes na sociedade permite que se extrapole o conteúdo "Ditadura Militar" e se parta em direção às práticas vigentes na contemporaneidade e, sem dúvida, tal virtualidade disposta pela necessidade de se produzir uma História possui um potencial orientador.

c) percepção da historicidade das produções culturais e relações sociais

"Liberdade de expressão era uma coisa que de fato nem existia. Aliás, existir até que existia sim, porém, dependendo do que você fosse expressar você era perseguido e torturado pela ditadura. Voltando a falar 
dos 'revoltosos', um deles, Chico Buarque, que compôs algumas músicas para acordar de vez a população. Quase todas as músicas que ele criava, a ditadura censurava. 'Cálice' era o nome de uma de suas músicas. Se hoje alguém, sem nenhum entendimento do que se passava há algumas décadas, seria difícil a compreensão das letras. Mas, para a população daquela época talvez não fosse difícil, já que eram assunto e realidade da época."

A relevância da legibilidade como componente da historicidade foi captada de maneira extremamente positiva, pois permite o acesso amplo a formas de interação e crítica cultural, possibilitando uma reflexão hermenêutica (porque foi isso que a aluna demonstrou em sua análise) necessária à racionalidade pretendida para o pensamento histórico.

Esta aluna revelou um senso crítico bastante agudo, cuja compreensão nos deveria remeter para além das aulas de História, embora acreditemos que elas tenham contribuído.

"Não somos nós que escolhemos quanto vamos ganhar mensalmente, quanto tempo um assassino ficará na cadeia, ou seja, a injustiça ainda está presente."

Aqui a crítica tornou-se consciente de problemas com a própria noção de democracia, pois, um risco ao se estudar a ditadura como momento de supressão das liberdades, é negativizar o passado e, por extensão, positivizar o presente. Tal clareza de concepção pode estar relacionada ao trabalho racionalmente orientado em produzir uma História.

Mas, o mais impressionante, sem dúvida, é a percepção de uma crise com relação aos valores, que a nossa época (a época dela, que não é mais a da ditadura) parece vivenciar.

"Hoje somos livres para nos expressarmos. Graças a essa 'liberdade de expressão' existem muitas intrigas, devido ao pré-conceito de cada um. Na ditadura militar era considerada imoralidade, dependendo do que tratava o assunto. Hoje muitos perdem seus valores com o uso do próprio corpo, afinal, não é considerado por eles mesmo como imoral. Hoje discutimos inúmeros assuntos, por isso existem tantos desentendimentos. ${ }^{8}$

\footnotetext{
${ }^{8}$ Uma vez mais remetemos ao texto de Carlos Fico anteriormente citado (ver nota 8).
} 
Será o sintoma de uma jovem consciente do alto grau de exposição em que se encontra a vida privada de cada um, virtualmente pelo menos, diante do aumento crescente das possibilidades de comunicação e da eficácia em produzir informação, aliado ao desejo em possuí-la e, claro, ao seu preço?

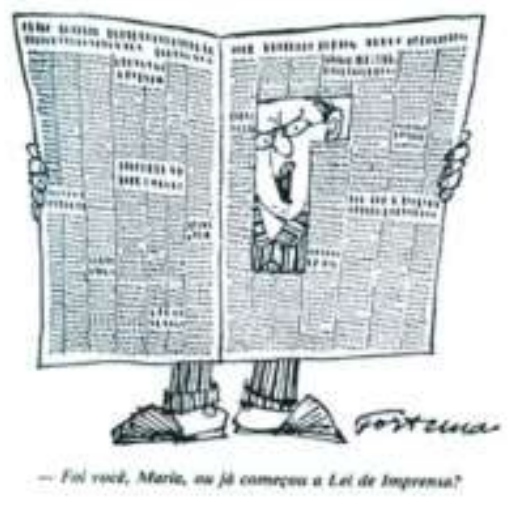

Figura 2 - Aqui os alunos puderam avaliar as dimensões da censura e da crítica feita por intelectuais da época.

d) capacidade de diferenciação e especificação da realidade histórica

I - "Todos sofreram conseqüências diretas por causa dos ideais dos governantes".

II - "Sim, pois os opressores tinham uma forma exageradamente moralista e autoritarista de governar. Tiravam os direitos da 'massa' esperando ter o silencio e o apoio deles. Para os que eram de forma indireta atingidos, bastava concordar com tudo e nada aconteceria. Já para os que de forma direta se fossem contra obtinham como resposta sessões de tortura com choques elétricos, palmatórias, golpes com barras de ferro, pau-de-arara, entre outros. Vejamos: 'Maurício Vieira Paiva, 24 anos, quintanista de engenharia, foi ligado a um magneto pelos dedos mínimos das mãos. Murilo Pinto da Silva, 22 anos, funcionário público, ficou com os pés descalços sobre as bordas de duas latas abertas [...]' (livro Ditadura Envergonhada, página 361). Nos exemplos de torturas dados acima, os dois se tratavam de pessoas orientadas e não de pessoas ignorantes ou sem conhecimento".

A aluna (por uma coincidência, não trato aqui de nenhum "aluno") demonstrou uma mudança quanto à consideração do conteúdo, uma vez 
que não mais engloba toda uma realidade a partir de um juízo generalizante, como no trecho I. Mas, o que é mais importante, mostra as diferenças e as exemplifica a partir das fontes, comentando-as em seguida (o que muitos historiadores ainda não fazem...). Assim, ela continua tratando dos estudantes como objeto de perseguição e se propõe a entender o porquê de outros seguimentos da população (que ela, sem ser politicamente correta, chama de ignorantes) não resistirem à ditadura:

"Estas mais desprovidas de conhecimento faziam parte da grande maioria, eles se conformavam com a situação ou sei lá, talvez era benéfico para eles, o Brasil que em anos anteriores ao regime militar sofria muito com inflações, desemprego, falta de poder de compra, custo de vida elevado entre outros, era o mesmo Brasil que crescia $10 \%$ na época da Ditadura."

A capacidade de compreender distinções sociais e, a partir delas, ações individuais no passado, permite tal exercício no presente, e contribui para um aumento da racionalidade da consciência histórica.

Desejamos dar um último exemplo.

e) problematização - estabelecimento de questões

"Agora, após ler essas características da ditadura, podemos fazer a pergunta: Então por que a ditadura tem 'fãs' até hoje? Afinal, muitas pessoas gostariam que ela voltasse, e a resposta é: porque naquela época a economia brasileira crescia grandemente ao ano, e também porque os militares apresentavam à população um falso moralismo e mostravam que aquilo que eles faziam era o melhor para a população, o melhor para o Brasil".

Esta capacidade de levantar as próprias questões a partir da documentação e da própria vivência nos parece ser um estágio bastante elaborado de consciência histórica - o limiar de uma cultura histórica, para usar mais uma expressão cara a Rüsen. Não propusemos esta indagação. A aluna é quem foi buscá-la.

A relação estabelecida com o atual sistema político parece ser esclarecedora: 
"Atualmente os políticos roubam, mesmo sabendo que a imprensa poderá mostrar para a população. Agora, imaginem com a Lei de Imprensa? Quantos desvios não teriam?!"

Essa tentativa de caracterizar as habilidades de cognição histórica desenvolvidas pelos alunos é algo quase temerário, pois beira a especulação. "Não é nada fácil" como diz Rüsen, "apontar as capacidades exatas que se adquire com o aprendizado da história" (2007, p. 104). Mas, uma vez que isto se refere a quaisquer conteúdos de consciência, cuja existência é meramente subjetiva e, por definição, inacessível, não significa que não possamos tentá-lo, como último esforço de um inabalável otimismo gnoseológico.

Por outro lado, esta amostra não é significativa, pois corresponde a cerca de $13 \%$ dos trabalhos produzidos, em sua totalidade. Uma vez, entretanto, que muitos alunos sequer tentaram escrever uma história, e copiaram-na do livro didático ${ }^{9}$, esse percentual sobe para cerca de $20 \%$. Percalços do sistema educacional. Há também casos - no entanto raros em que nada pareceu mudar.

Se comparado com o desempenho em bimestres anteriores, os alunos apresentaram um ganho de capacidade crítica notável. Isso não seria possível, em nossa opinião, se prevalecesse o método da cópia didática - isto é, se os alunos se limitassem a registrar o que o professor Ihes transmite.

Tal qual compreendi a tese de Rüsen, o aprendizado se configura como uma transformação qualitativa dos dados apreendidos, uma vez que o

\footnotetext{
9 O livro didático dos alunos, (BOULOS JUNIOR, 2009) ao qual foi solicitado que não recorressem, apresenta a Ditadura Militar em dois capítulos, de acordo com a postura dos presidentes. O Capítulo 15, "Regime Militar: de Castelo Branco a Médici" retoma o Golpe de 64, já antecipado em capítulo sobre Kubitscheck e João Goulart, e apresenta as principais medidas presidenciais (como os Atos Institucionais) e a produção cultural de "resistência". O Capítulo 16, "A distensão do Regime Militar: de Geisel a Sarney" segue a mesma linha. Ambos são fartamente ilustrados, apresentando documentos, em sua maioria, imagéticos: fotografias, charges etc. As imagens são, com freqüência, trabalhadas com comentários ou perguntas e não assumem o tom de ilustração. A idéia de que os alunos não recorressem ao livro não diz respeito a uma suposta má qualidade, mas antes, à proposta de evitar esquemas interpretativos normalmente oferecidos por este tipo de publicação.
} 
aluno elabora subjetivamente a sua inserção num contexto referenciável, mediante a transformação do seu passado - do seu país, dos seus valores em História. Então, é de fato escrevendo - eles mesmos - uma História, baseados nos critérios de racionalidade específicos da disciplina, que será possível essa subjetivação.

O contato com um vasto conjunto de fontes documentais e com a diversidade dos pontos de vista permite ao estudante compreender a complexidade do acontecer humano e a distância entre realidade e discurso. Isso não seria possível apenas lendo o livro didático. Cabe aqui uma crítica à noção de paideuma ${ }^{10}$, que o livro didático acaba por incorporar: revelar a seletividade e a dificuldade em se produzir uma história, evitando a aderência irrefletida ao conteúdo expresso nos livros escolares. Compreendê-los como um auxílio, não como uma fonte.

Ou seja, pouco importa que se decore o livro didático: não faz diferença alguma, se ficar só nisso.

Aplicamos mais um teste, após a primeira experiência de escrita de uma "História da Ditadura", na tentativa de compreender se, de fato, a produção de uma História, por parte dos alunos, resultou-lhes em um acréscimo com relação à capacidade de refletir sobre o tempo, sobre a História.

A pergunta foi a seguinte: "Durante uma aula de História, realizada junto ao $1^{\circ}$ ano do Ensino Médio, um dos alunos levantou a mão e fez a seguinte pergunta: 'Professor, o senhor nos fala tanto de História, e de como ela é importante para as vidas das pessoas, mas o que vejo são os velhos problemas da natureza humana se repetirem ao longo dos séculos; ricos oprimindo os pobres, guerras, más intenções. Parece que as coisas nunca mudam!'

Baseado(a) em suas aulas de História, estabeleça um diálogo com este aluno, apontando-Ihe seu ponto de vista a respeito do problema que ele levantou."

${ }^{10}$ Refiro-me, naturalmente, à concepção de ensino idealizada pelo grande poeta americano Ezra Pound: "a ordenação do conhecimento de modo que o próximo homem (ou geração) possa achar, o mais rapidamente possível, a parte viva dele, e gastar um mínimo de tempo com itens obsoletos". (POUND, 1970, p. 12). 
Uma série de alunos ratificou a posição do aluno hipotético, demonstrando certo pessimismo com relação às perspectivas de futuro, uma espécie de descrença geral nas possibilidades de melhoria e na mudança da História.

Em um dos casos, entretanto, obtivemos uma resposta que atende à necessidade de encontrar na História uma possibilidade formativa (RÜSEN, 2006, p. 8), embora não possamos recuar em busca de uma magistra vitae, por conta do processo de temporalização da História que possibilitou o surgimento da História como Ciência (KOSELLECK, 2001, p. 47). A resposta foi assim: "É o que acontece com a História. Sabemos o que aconteceu, do que eles fizeram e tiveram como conseqüência, mas não adianta de nada, porque não trazemos isso como exemplo para nossas vidas, ou seja, de que adianta a teoria se não tem a prática?".

É curioso observar a associação feita entre História e teoria: o que nos afigura por parte desta resposta é que a função da História só se concretizaria se aliada a uma práxis.

Esta é a concepção de outra resposta obtida entre os alunos: "O mundo muda, são as pessoas que não tomam iniciativa para fazer a diferença, hoje em dia não precisamos ter medo, mas quem disse que temos liberdade, quem disse?".

Esta práxis se torna ainda mais sublinhada quando um tema atual é abordado a partir de uma questão teórica, como a que foi levantada. Vejase este exemplo, de outro aluno: "A violência no nosso Brasil está cada vez pior. O Rio de Janeiro nem parece mais aquela cidade que muitos sonham em morar, no Rio de Janeiro até as classes mais altas, burguesas, estão sendo atingidas".

Há ainda a capacidade de problematizar um contexto social, como na seguinte resposta: "Eu creio que a questão a respeito de guerras, conflitos, acontece quando não há outro meio de resolução, quando não há diálogo ou então por mera irracionalidade, para mostrar o poder que tem em mãos".

O período abordado no 90 ano do Ensino Fundamental é a "História Contemporânea", que significa, mais ou menos, Imperialismo, Guerras Mundiais, Crise de 29, Revolução Russa, Guerra de Canudos, Regime 
Militar, dentre outros conflitos. Uma pergunta que trate de refletir sobre essa peculiaridade do que é narrado do século $X X$, deve abrir a possibilidade de expandir os horizontes a respeito da experiência humana, que, como queremos acreditar não se limita a relações de força, embora elas existam em diversos níveis (essa limitação pode ter origem numa metáfora radical, como "Homo homini lupus"). Como disse um aluno ${ }^{11}$, em resposta à indagação referida mais acima, deveríamos tentar uma "História de amor".

O que estamos tentando fazer é, na verdade, avaliar se é possível alcançar uma potencialização da consciência histórica (com capacidade de auto-orientação identitária), pelo método de escritura de uma História.

Vejamos mais uma resposta, desta vez, integralmente transcrita:

"Em minha opinião, a História não são (sic) só velhos problemas da natureza humana. Para mim a História é fundamental, pois sem ela não saberíamos de onde viemos apesar de haver várias teorias, mas não saberíamos o que fizeram nossos antepassados, o que sofreram e o que enfrentaram para que o modo de vida hoje seja como ele é. Tudo é História, o presente de hoje será o passado de amanhã. Muitas pessoas dizem que tudo (que) é passado não influencia nada nos dias atuais, mas com certeza essas pessoas vão querer ser lembradas no futuro. A História não se faz só no passado, a História faz parte de nossa nação, de tudo o que vivemos. Tem seus pontos negativos, como o aluno citou, mas tem vitórias que ele esqueceu de citar. Mas assim como no passado hoje também ocorrem coisas ruins. A vida é assim, a História é assim."

Esta capacidade reflexiva em teorizar a temporalidade do acontecer humano talvez nos permita compreender como uma possibilidade real o desenvolvimento de um ponto de vista racionalmente orientado sobre a História em sala de aula. Isto atende ao programa de BERGMANN (1990, p. 29) sobre as tarefas empírica, normativa e reflexiva da Didática da História.

${ }^{11}$ Ver a nota número 2. 


\section{História e Comunidade}

Tal perspectiva não é isenta de valores, nem assim o desejamos. Em Teoria da História, a ousadia em assumir um ponto de vista e defendê-lo (é estranho chamar isto de ousadia, quando deveria ser algo banal, nem mesmo digno de menção) é na verdade uma prudência com relação a malentendidos.

A questão sobre como partir da História e chegar à Comunidade deve ser respondida do seguinte ponto de vista: definir o que se entende por "comunidade", ou "educação comunitária", justificar a importância de tal empreendimento e dizer como esse itinerário é possível.

O filósofo Martin Buber desenvolveu um pensamento complexo a respeito do diálogo, da comunidade e das diversas formas do inter-humano, definidas pelo conceito de relação por oposição à experiência, pensamento este que, segundo acreditamos, deve ser mais estudado e potencializado pela perspectiva da formação histórica.

Para Buber, comunidade como comunhão de valores não pode ser percebida como uma esfera isolada da prática social, "que se erige ao lado da vida" (BUBER, 2008, p. 85), na mera evanescência das alianças comunitárias. Pelo contrário, deve englobar a totalidade da existência dos seres humanos, não porque seja possível viver em estado de perpétua reciprocidade, no face-a-face do Eu e Tu - isto não é possível; mas totalidade, pelo fato da relação poder acontecer, isto é, encontrar disposição, capacidade, por parte dos sujeitos, a qualquer momento.

Educação como capacitação para relação. Formação histórica ${ }^{12}$ como capacitação para a relação. Didática da História como via para a formação histórica.

A necessidade de comunidade se verifica pelo alto grau de massificação, burocratização e desumanização das relações entre humanos $^{13}$.

\footnotetext{
12 Ver mais adiante, nota 12.

13 Buber baseia-se, neste ensaio, na obra de Tönnies, onde há uma distinção radical entre comunidade e sociedade.
} 
O diálogo como imperativo humanístico não se baseia, então, na comunhão de valores, mas deve existir a partir das diferenças. Não é com meu semelhante que devo dialogar - mas com meu diferente. A possibilidade das relações comunitárias deve se erguer "não sobre homens formados e ordenados de modo semelhante, mas sim sobre pessoas que, formadas e ordenadas diferentemente, mantém uma autêntica relação entre si" (BUBER, 2008, p. 87).

Assim, quando nos referimos às repostas produzidas por alunos em sala de aula, verificando não haver uma unidade ao nível de sala, e, às vezes, ao nível de texto (como mostramos, as habilidades críticas observadas geralmente aparecem dispersas entre os alunos), devemos nos perguntar: a apreensão dos "resultados da consciência histórica", orientados para a vida comunitária, tal qual o diálogo surgido da subjetividade potencializada possibilita, deve, necessariamente, almejar a sistematização? Não é precisamente daí que decorrem as dificuldades analíticas?

Conseguir lidar com a multiplicidade, não com a unidade.

Não se trata de buscar restaurar, como valor imperativo conscientemente assumido, a possibilidade orgânica da comunidade tal qual a imaginamos na época de ouro dos primórdios (que não deixa de ser uma infância) - esta, de qualquer forma, não nos é mais possível. O que pode ser assumido, legitimamente, publicamente, sem quaisquer impedimentos teóricos, mas talvez com algum risco pessoal, é o desejo de relação, de reciprocidade, que não se encontrará facilmente - e estamos sendo excessivamente otimistas - nas instituições como a Escola ou o Estado. É por isso que o conhecimento histórico extrapola, necessariamente, os limites do currículo e da metodologia escolar e deve ser "fabricado" como um "instantâneo"14, a partir dos improvisos, da visita ao shopping, no intervalo das aulas, nas festinhas de fim de ano. "Aquele que quer educar não educa. O que educa é, em última análise, o espontâneo" (BUBER, 2008, p. 90). A comunicação alcançada é revelação - diálogo com o outro, presente e passado. Esta é a possibilidade da comunidade e da história.

${ }^{14}$ A expressão vem, como se pode imaginar, de Benjamin. Ver nas Passagens, o capítulo sobre "Teoria do Conhecimento e Teoria do Progresso" (2009, p. 504). 
Mas a formação histórica capacita para o diálogo.

Formação ${ }^{15}$ é a capacidade de se contrapor à alteridade do passado, de levantar o véu da familiaridade que se tem com o passado camuflado na vida prática presente e de reconhecer 0 estranho, assim descoberto, como próprio. Formação é uma instituição dos pressupostos da subjetividade no manejo cognitivo do passado (RÜSEN, 2007, p. 108).

Assim, a disciplina da História, como teoria efetivamente traduzida em atividade intelectual - por parte dos alunos - sem o recurso aos esquematismos dos livros didáticos, ou ao sistema de cola didática, possibilita o sujeito a se inserir racionalmente em seu mundo - a considerálo enquanto tal - ou seja, argumentativamente, dialogicamente, comunitariamente.

Lembrando de nossa epígrafe: o apelo de um de nossos alunos é semelhante ao lançado por Buber:

Por exemplo: a história. Ela pode ser ensinada não como a História dos Estados: que Estado se levantou contra qual (...) Ao contrário, quando se ensinar história, dever-se-ia partir da questão: quantas comunidades, em certa época, foram constituídas entre os homens? Como, de que modo, com que dificuldades, sob que resistências estas batalhas subterrâneas - que são expressivamente mais importantes para a humanidade do que as batalhas abertas, visíveis, sobre as quais, aliás, tanto se fala - aconteceram? (2008, p. 98).

\section{Considerações finais}

Através de uma "razão histórica" - isto é, de uma instância das considerações válidas para a apreensão subjetiva do tempo - abordar as outras racionalidades em funcionamento na sociedade, como a razão política (tratamos, a título de exemplo, um estudo realizado pelos alunos sobre a Ditadura Militar).

A História se torna o meio racional de se abordar outras racionalidades, por excelência. Tal formulação só é possível mediante a

${ }^{15}$ Bildung. Formação histórica: "capacidade de uma determinada constituição narrativa de sentido" (RÜSEN, 2007, p. 104). 
admissão de que a reflexão (orientada por pressupostos críticos) sobre o tempo é o caminho menos incerto para se compreender as ações humanas, por não ensejar uma substância enquanto auto-realização - por admitir a precariedade dos pontos de vista (de qualquer forma, irredutíveis) como o meio mais seguro (de um ponto de vista político e moral) para o exercício da liberdade. Tal precariedade, expliquemo-nos, não passa da suprema desconfiança diante de verdades irretorquíveis - mas ela não é irretorquível, dado que segue regras de potencialização da subjetividade mediante controle empírico, lógico e intersubjetivo.

A imersão, ou antes, a submersão em uma cultura histórica, traz a tona, lado a lado à relatividade das experiências e das idéias, a elevada possibilidade do diálogo.

Tal esfera, humana por excelência (assim como a razão), possui uma dupla vitalidade, capaz de fazer "viver" o saber histórico: por um lado possibilita a relação dos dados do mundo empírico de uma perspectiva sincrônica e diacrônica, para usar uma terminologia cara aos estruturalistas, onde essa estrutura converte-se numa imagem de mundo ${ }^{16}$, agora narrativamente apreensível; por outro lado, o elemento dialógico se presta à não-segregação dos resultados da representação temporal (consciência histórica como consciência da diferença), permitindo que se possa dialogar com o diferente - isto é, falar ao outro, e deixar que ele fale.

Para concluirmos provisoriamente nossa argumentação, sigamos o roteiro elaborado por RÜSEN (2006, p. 9): "A didática da educação em história estabelece os objetivos e as formas de educação histórica dentro de um dado contexto político, social, cultural e institucional". Temos o ideal de comunidade como horizonte nestes contextos nos quais se estabelece a Educação Histórica. "A metodologia de instrução em história estabelece os meios práticos pelos quais estes objetivos são alcançados" (RÜSEN 2006, p. 9). Aqui entra a proposta de escritura de uma história por parte dos alunos, e o ideal de formação histórica a ser perseguido.

Ensino de História com um coeficiente humanístico: diálogo e comunidade como ideais cognitivos e morais do conhecimento

${ }^{16}$ Essa reflexão foi produzida a partir da crítica de Dilthey ao pensamento de Kant. Ver (DILTHEY, 1974, p. 93). 
cientificamente produzido. O aluno só se tornará capacitado para o diálogo, quando deixarmos de falar por ele. Quando o auxiliarmos - através de nossa especialidade, o conhecimento histórico - a aumentar o grau de consciência que ele tem de si mesmo, de seu mundo e do Outro.

\section{Referências}

ADORNO, T. W. Educação e Emancipação. São Paulo: Paz e Terra, 2006.

ALMEIDA, H. T. de; WEIS, Luiz. Carro zero e Pau-de-arara: o cotidiano da oposição de classe média ao regime militar. In NOVAIS, F. (Coord.);

SCHWARTZ, L. M. (Org.). História da Vida Privada no Brasil. Contrastes da intimidade contemporânea. São Paulo: Companhia das Letras, 1998, p. 319-409.

ARAÚJO, P. C. de. Eu não sou cachorro não. Música Popular Cafona e Ditadura Militar. RJ/SP: Record, 2002, p. 51-82.

AZEVEDo, J. M. L. de. A Educação como Política Pública. São Paulo: Editora Autores Associados, 1997.

BENJAMIN, W. Obras Escolhidas. Volume I. Brasiliense, 1999. Passagens. SP: Editora da Unicamp, 2009.

BERGAMANN, K.. "A História na Reflexão Didática". Revista Brasileira de História. São Paulo. v. 9, n. 19, p. 29-42, set. 89/ fev. 90.

BOULOS JR, A. História, sociedade e cidadania. $9^{\circ}$ ano. São Paulo: FTD, 2009.

BLOCH, Marc. O oficio do historiador. Rio de Janeiro: Jorge Zahar Editor, 1998.

BUBER, M. Eu e Tu. São Paulo: Centauro, 2001. . Sobre Comunidade. São Paulo: Perspectiva, 2008.

CERTEAU, M. de. A escrita da História. Rio de Janeiro: Forense Universitária, 2010.

DILTHEY, W. Teoria de las concepciones del mundo. Revista de Occidente, Madrid, 1974.

FERREIRA JR, Amarílio; BITTAR, Marisa. Educação e ideologia tecnocrática na ditadura militar. Cad. CEDES. Campinas, v. 28, n. 76, dez/2008. 
FICO, Carlos. Versões e controvérsias sobre 1964 e a ditadura militar. Revista Brasileira História, São Paulo, v. 24, n. 47, 2004. Disponível em http://www.scielo.br/scielo.php? script=sci_arttext\&pid = S010201882004000100003 \# tx15. Acesso em: 17/09/2011

GASPARI, É. A ditadura envergonhada. São Paulo: Companhia das Letras, 2002; p. 357-362.

MARTINS, E. de R. Memória Experiência Vivida: a domesticação do tempo na História. Antíteses, v. 1, n. 1, jan./jun. de 2008, p. 17-30 Disponível em http://www.uel.br/revistas/uel/ind. php/antiteses, acesso em 20/05/2009.

O caráter relacional do conhecimento Histórico. In COSTA, C. B. da (Org.). Um passeio com Clio. Revista do Programa de Pós Graduação da Universidade de Brasília, 2002 pp. 11-25.

POUND, E. ABC de literatura. São Paulo: Cultrix, 1970.

RÜSEN, J. Didática da História: passado, presente e perspectivas a partir do caso alemão. Práxis Educativa. Ponta Grossa, PR. v. 1, n. 2, p. 07-16, jul./dez. 2006.

História Viva. Brasília: Universidade de Brasília, 2007. . Razão Histórica. Brasília: Universidade de Brasília, 2001.

VEYNE, P. Como se escreve a História. Brasília: Editora da UnB, 1982.

WEBER, M. Metodologia das Ciências Sociais. v.1, São Paulo: Editora da Unicamp, 1996. 